\title{
Amorphous $\mathrm{LiCoO}_{2}$-based Positive Electrode Active Materials with Good Formability for All-Solid-State Rechargeable Batteries
}

\author{
Kenji Nagao, Yuka Nagata, Atsushi Sakuda, Akitoshi Hayashi* and Masahiro Tatsumisago \\ *Corresponding author: hayashi@chem.osakafu-u.ac.jp
}

Department of Applied Chemistry, Graduate School of Engineering, Osaka Prefecture University, 1-1, Gakuen-cho, Naka-ku, Sakai, Osaka 599-8531, Japan

\section{ABSTRACT}

Amorphous $\mathrm{LiCoO}_{2}$-based positive electrode materials are synthesized by a mechanical milling technique. As a lithium oxy-acid, $\mathrm{Li}_{2} \mathrm{SO}_{4}, \mathrm{Li}_{3} \mathrm{PO}_{4}, \mathrm{Li}_{3} \mathrm{BO}_{3}, \mathrm{Li}_{2} \mathrm{CO}_{3}$, and $\mathrm{LiNO}_{3}$ are selected and milled with $\mathrm{LiCoO}_{2}$. XRD patterns indicate that reaction between $\mathrm{LiCoO}_{2}$ and these lithium oxy-acids proceeds. Amorphization mainly occurs, and several broad peaks attributable to cubic $\mathrm{LiCoO}_{2}$ are observed in all the samples. These amorphous active materials show mixed conductivities of electron and lithium ion. All-solid-state cells using the prepared amorphous active materials and the $\mathrm{Li}_{2.9} \mathrm{~B}_{0.9} \mathrm{~S}_{0.1} \mathrm{O}_{3.1}$ glass-ceramic electrolyte are fabricated and their charge-discharge properties are examined. The cells with only the $80 \mathrm{LiCoO}_{2} \cdot 20 \mathrm{Li}_{2} \mathrm{SO}_{4}(\mathrm{~mol} \%)$ and the $80 \mathrm{LiCoO}_{2} \cdot 20 \mathrm{Li}_{3} \mathrm{PO}_{4}$ active materials function as secondary batteries. This is because higher lithium ionic conductivities are obtained in the $80 \mathrm{LiCoO}_{2} \cdot 20 \mathrm{Li}_{2} \mathrm{SO}_{4}$ and $80 \mathrm{LiCoO}_{2} \cdot 20 \mathrm{Li}_{3} \mathrm{PO}_{4}$ active materials than in the others. The largest capacity is obtained in the cell with the $80 \mathrm{LiCoO}_{2} \cdot 20 \mathrm{Li}_{2} \mathrm{SO}_{4}$ active material because of its good formability and high lithium ionic conductivity. In addition, the cell with the $80 \mathrm{LiCoO}_{2} \cdot 20 \mathrm{Li}_{2} \mathrm{SO}_{4}$ positive electrode active material shows the better cycle and rate performance than that with the crystalline $\mathrm{LiCoO}_{2}$. It is noted that the amorphization with lithium oxy-acids is a promising technique for achieving a novel active material with better electrochemical performance.

\section{INTRODUCTION}

All-solid-state lithium secondary batteries have attracted great attention because of safety and reliability [1]. For commercial use of all-solid-state battery, development of solid electrolytes with high lithium ionic conductivity is important. We have reported the mechanochemical synthesis of sulfide and oxide glass electrolytes [2-9]. In particular, the $\mathrm{Li}_{3} \mathrm{BO}_{3}-\mathrm{Li}_{2} \mathrm{SO}_{4}-\mathrm{Li}_{2} \mathrm{CO}_{3}$ glass-ceramic electrolytes prepared by mechanical milling and consecutive heat treatment showed relatively high lithium ionic conductivity of $10^{-6}-10^{-5}$ $\mathrm{S} \mathrm{cm}^{-1}$ at room temperature [6-9]. In addition, these oxide glass-ceramic electrolytes easily deform and large contact area with active materials can be achieved simply by pressing at room temperature. This good deformation property is favorable for the construction of bulk-type all-oxide solid-state batteries. For large scale application, the energy density of 
the batteries should be increased. The use of active materials with larger capacity and the increase of their content in an electrode layer are effective for increasing energy density of batteries. In the typical all-solid-state batteries, composite electrodes composed of active materials, solid electrolytes, and carbon conductive additives are used, and, the decreasing the electrolyte and carbon contents is desirable for increasing energy density of the batteries. Ultimately, an electrode layer composed of only active materials is favorable for achieving the highest energy density. To realize these batteries, an active material with both high deformability and high conductivity of electrons and lithium ions are needed to develop.

As a positive electrode active material, typically crystalline materials with layered structure such as hexagonal $\mathrm{LiCoO}_{2}[10]$ and $\mathrm{LiNi}_{1 / 3} \mathrm{Mn}_{1 / 3} \mathrm{Co}_{1 / 3} \mathrm{O}_{2}$ [11,12] are used because of their relatively high capacity and high operation voltage. We believe there is a possibility for amorphous materials as an alternative candidate for positive electrode active materials. Amorphization of active materials is potentially capable of achieving higher capacity because of the presence of additional stable sites for lithium ions on the basis of open and random structure in amorphous materials. For example, amorphous $\mathrm{V}_{2} \mathrm{O}_{5}, \mathrm{TiS}_{3}$ and $\mathrm{MoS}_{3}$ exhibit the higher capacity than crystalline ones [13-15]. In addition, Sabi et al. have reported the preparation of the amorphous positive electrode films $\mathrm{Li}_{x} \mathrm{M}_{y} \mathrm{PO}_{z}(\mathrm{M}=$ $\mathrm{Ni}, \mathrm{Co}$, etc.) and the fabrication of thin-film type all-solid-state batteries using a sputtering technique [16]. The thin-film type all-solid-state batteries operated as secondary batteries and showed the large capacity of $330 \mathrm{mAh} \mathrm{g}^{-1}$ with the relatively high average discharge voltage of $c a .3 \mathrm{~V} \mathrm{vs} \mathrm{Li}^{+} / \mathrm{Li}$. Therefore, such amorphous positive electrode active materials are promising as an active material for all-solid-state batteries with high energy density. Nevertheless, it is difficult to apply thin-film batteries to larger scale energy storage systems because of limited amounts of active materials.

We have therefore specifically examined the preparation of the amorphous oxide electrode particles suitable for bulk-type all-solid-state batteries. Recently, we have developed the amorphous $\mathrm{LiCoO}_{2}-\mathrm{Li}_{2} \mathrm{SO}_{4}$ positive electrode active material particles and fabricated bulk-type all-solid-state batteries using these particles [17]. The amorphous $\mathrm{Li}_{1.2} \mathrm{Co}_{0.8} \mathrm{~S}_{0.2} \mathrm{O}_{2.4}\left(80 \mathrm{LiCoO}_{2} \cdot 20 \mathrm{Li}_{2} \mathrm{SO}_{4}(\mathrm{~mol} \%)\right)$ showed relatively high mixed conductivity and good formability. Bulk-type all-oxide solid-state cells (Li-In alloy / amorphous $\mathrm{Li}_{1+x} \mathrm{Co}_{1-x} \mathrm{~S}_{x} \mathrm{O}_{2+2 x}$ ) were fabricated by pressing the particles at room temperature. Although the cell with the milled only $\mathrm{LiCoO}_{2}(x=100)$ showed no capacity, the cell using the $\mathrm{Li}_{1.2} \mathrm{Co}_{0.8} \mathrm{~S}_{0.2} \mathrm{O}_{2.4}(x=0.2)$ electrode with $c a .150 \mu \mathrm{m}$ thickness operated as a secondary battery at $100^{\circ} \mathrm{C}$. This improvement was caused by the enhancement of formability and lithium ion conductivity by the addition of $\mathrm{Li}_{2} \mathrm{SO}_{4}$. Therefore, the amorphous active materials prepared from lithium transition metal oxides and lithium oxy-acids are promising for the all-solid-state batteries. However, the other lithium oxy-acids have not been examined yet.

Here, we report the mechanochemical synthesis of the amorphous $\mathrm{LiCoO}_{2}$-based active materials with various lithium oxy-acids $\left(e g . \mathrm{Li}_{2} \mathrm{SO}_{4}, \mathrm{Li}_{3} \mathrm{PO}_{4}, \mathrm{Li}_{3} \mathrm{BO}_{3}, \mathrm{Li}_{2} \mathrm{CO}_{3}\right.$ and $\mathrm{LiNO}_{3}$ ). The structure and conduction properties for the amorphous $\mathrm{LiCoO}_{2}-$ based active materials were evaluated. In addition, all-solid-state cells using the prepared amorphous active materials were fabricated and their charge-discharge properties were investigated.

\section{EXPERIMENTAL DETAILS}

Amorphous $\mathrm{LiCoO}_{2}$-based positive electrode active materials were prepared from $\mathrm{LiCoO}_{2}\left(>99 \%\right.$, Nippon Chemical Industrial) and one of lithium oxy-acids $\mathrm{Li}_{2} \mathrm{SO}_{4}$, $\mathrm{Li}_{3} \mathrm{PO}_{4}, \mathrm{Li}_{3} \mathrm{BO}_{3}, \mathrm{Li}_{2} \mathrm{CO}_{3}$ and $\mathrm{LiNO}_{3} . \mathrm{Li}_{2} \mathrm{SO}_{4} \cdot \mathrm{H}_{2} \mathrm{O}(99.9 \%$, Wako Pure Chem.) was heat- 
treated at $300^{\circ} \mathrm{C}$ for $3 \mathrm{~h}$ in dry $\mathrm{Ar}$ atmosphere to remove water molecules, and then $\mathrm{Li}_{2} \mathrm{SO}_{4}$ crystal was obtained. $\mathrm{Li}_{3} \mathrm{BO}_{3}$ crystal was synthesized by conventional solid state reaction. A mixture of $\mathrm{LiOH} \cdot \mathrm{H}_{2} \mathrm{O}\left(>99 \%\right.$; Wako Pure Chem.) and $\mathrm{H}_{3} \mathrm{BO}_{3}(>99 \%$; Wako Pure Chem.) was heated in an alumina crucible at $500^{\circ} \mathrm{C}$. After this calcined powder was grounded, the powder was sintered at $600^{\circ} \mathrm{C}$ for $2 \mathrm{~h}$ and then $\mathrm{Li}_{3} \mathrm{BO}_{3}$ crystal was obtained. $\mathrm{Li}_{3} \mathrm{PO}_{4}$ (Aldrich Chem.), $\mathrm{Li}_{2} \mathrm{CO}_{3}\left(>99 \%\right.$; Wako Pure Chem.) and $\mathrm{LiNO}_{3}(99.9 \%$; Wako Pure Chem.) crystals were heated at $130^{\circ} \mathrm{C}$ for $12 \mathrm{~h}$ in vacuum to remove the surface absorption water. The $\mathrm{LiCoO}_{2}$-based active materials were synthesized by a mechanochemical technique using a planetary ball-milling apparatus (Pulverisette 7; Fritsch $\mathrm{GmbH})$. A mixture of $\mathrm{LiCoO}_{2}$ and one of lithium oxy-acids $\left(\mathrm{Li}_{2} \mathrm{SO}_{4}, \mathrm{Li}_{3} \mathrm{PO}_{4}\right.$, $\mathrm{Li}_{3} \mathrm{BO}_{3}, \mathrm{Li}_{2} \mathrm{CO}_{3}$ and $\mathrm{LiNO}_{3}$ ) was put into a $45 \mathrm{~mL}$ zirconia pot with 160 zirconia balls (5 $\mathrm{mm}$ in diameter) and milled at the rotating speed of $370 \mathrm{rpm}$ for $50 \mathrm{~h}$. All processes were conducted in a dry Ar atmosphere. After the milling, amorphous $\mathrm{LiCoO}_{2}$-based positive electrode materials were obtained.

$\mathrm{X}$-ray diffraction (XRD) measurements $(\mathrm{CuK} \alpha)$ were conducted using a diffractiometer (Ultima IV; Rigaku). Electronic and lithium ionic conductivities for the pelletized amorphous active materials were evaluated by AC impedance and DC polarization measurements [17]. A cross-section of the pressed pellets was prepared using Ar ion milling system (IM4000; Hitachi High-Technologies), followed by being analysed with a field-emission scanning electron microscope (FE-SEM, SU8200; Hitachi HighTechnologies).

All-solid-state cells ( $\mathrm{Li}-\mathrm{In} / \mathrm{Li}_{2.9} \mathrm{~B}_{0.9} \mathrm{~S}_{0.1} \mathrm{O}_{3.1}$ glass-ceramic electrolyte $[6,8] /$ amorphous $\mathrm{LiCoO}_{2}$-based active materials) were constructed to investigate their electrochemical performances. The positive electrodes were composed of only the prepared amorphous $\mathrm{LiCoO}_{2}$-based active materials with no solid electrolytes and conductive additives. Stainless steel powders were used as a current collector at the positive electrode side for securing electronic conduction and mechanical strength of the pellet. For the separator layer, the $\mathrm{Li}_{2.9} \mathrm{~B}_{0.9} \mathrm{~S}_{0.1} \mathrm{O}_{3.1}$ glass-ceramic electrolyte $[6,8]$ was used because of its good formability and high lithium ionic conductivity of $8.5 \times 10^{-4} \mathrm{~S} \mathrm{~cm}^{-1}$ at $100^{\circ} \mathrm{C}$. Three-layer pellets consisting of the current collector, positive electrode and separator layers were prepared by pressing the powders under $720 \mathrm{MPa}$ at room temperature. The pellets were heat treated at $290^{\circ} \mathrm{C}$ for $2 \mathrm{~h}$ to increase the conductivity of the $\mathrm{Li}_{2.9} \mathrm{~B}_{0.9} \mathrm{~S}_{0.1} \mathrm{O}_{3.1}$ glass electrolyte by crystallization. Indium foil $(99.999 \% ; 0.3 \mathrm{~mm}$ thickness; Furuuchi Chem.) and lithium foil (99.99\%; $0.25 \mathrm{~mm}$ thickness; Furuuchi Chem.), as an alloy negative electrode, and copper foil, as a negative electrode current collector, were attached to the pellet, and pressed at $120 \mathrm{MPa}$. The all-solid-state cells were charged and discharged using a charge-discharge measuring device (BTS-2004; Nagano) at $100^{\circ} \mathrm{C}$.

\section{RESULTS AND DISCUSSION}

Mechanical milling was carried out for the $80 \mathrm{LiCoO}_{2} \cdot 20 \mathrm{Li}_{x} \mathrm{MO}_{y}(\mathrm{~mol} \%)$ $\left(\mathrm{Li}_{x} \mathrm{MO}_{y}: \mathrm{Li}_{2} \mathrm{SO}_{4}, \mathrm{Li}_{3} \mathrm{PO}_{4}, \mathrm{Li}_{3} \mathrm{BO}_{3}, \mathrm{Li}_{2} \mathrm{CO}_{3}\right.$ and $\mathrm{LiNO}_{3}$ ) composition. In our previous study about the system $\mathrm{LiCoO}_{2}-\mathrm{Li}_{2} \mathrm{SO}_{4}$, the largest capacity was obtained at the $80 \mathrm{LiCoO}_{2} \cdot 20 \mathrm{Li}_{2} \mathrm{SO}_{4}(\mathrm{~mol} \%)$ composition [17]. Therefore, we specifically prepared the $\mathrm{LiCoO}_{2}$-based active materials at the $80 \mathrm{~mol} \%$ of $\mathrm{LiCoO}_{2}$. Figure 1a shows the XRD patterns for the amorphous $\mathrm{LiCoO}_{2}$-based active materials after milled for $50 \mathrm{~h}$. The peaks attributable to starting materials of hexagonal $\mathrm{LiCoO}_{2}$ and lithium oxy-acid were not observed, and amorphous samples were thus mainly obtained by milling at all the compositions. Several broad peaks attributable to cubic $\mathrm{LiCoO}_{2}$ were also observed. 
During mechanochemical process, the layered rock-salt type (hexagonal) $\mathrm{LiCoO}_{2}$ transforms to the cubic rock-salt phase, where $\mathrm{Co}^{3+}$ and $\mathrm{Li}^{+}$ions are ordered randomly in cation sites [18]. TEM observation for the $80 \mathrm{LiCoO}_{2} \cdot 20 \mathrm{Li}_{2} \mathrm{SO}_{4}$ active material indicated that nano-sized cubic $\mathrm{LiCoO}_{2}$ crystals were embedded in the $\mathrm{LiCoO}_{2}-\mathrm{Li}_{2} \mathrm{SO}_{4}$ amorphous matrix [17]. The similar structures are expected to be obtained in the other samples. The cubic $\mathrm{LiCoO}_{2}$ is electrochemically inactive [18], and the amorphous matrix should act as an active material; we thus call the prepared electrodes as amorphous ones in this study.
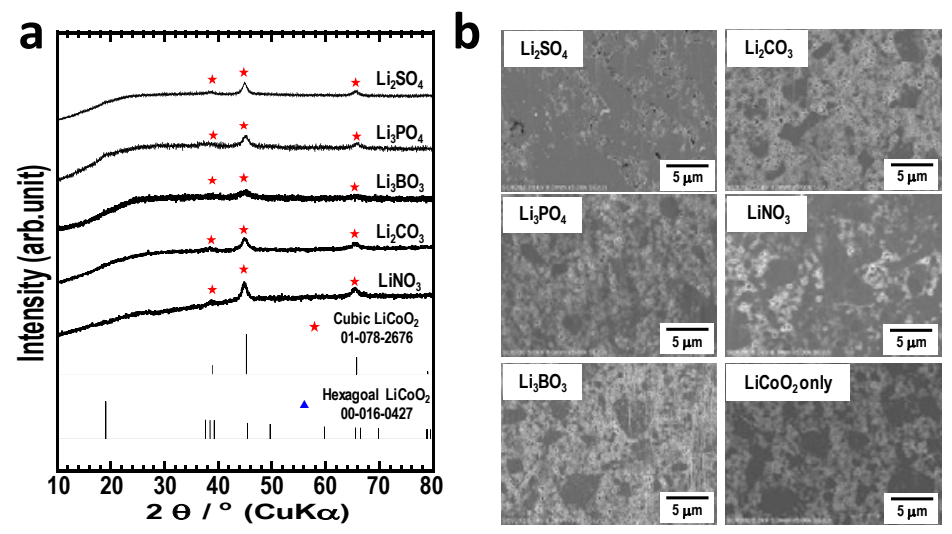

Figure 1 (a) XRD patterns for the amorphous $80 \mathrm{LiCoO}_{2} \cdot 20 \mathrm{Li}_{x} \mathrm{MO}_{y}\left(\mathrm{Li}_{x} \mathrm{MO}_{y}: \mathrm{Li}_{2} \mathrm{SO}_{4}, \mathrm{Li}_{3} \mathrm{PO}_{4}, \mathrm{Li}_{3} \mathrm{BO}_{3}, \mathrm{Li}_{2} \mathrm{CO}_{3}\right.$, and $\left.\mathrm{LiNO}_{3}\right)$ after milled for 50 hours. (b) Cross-sectional SEM images for the amorphous $80 \mathrm{LiCoO}_{2} \cdot 20 \mathrm{Li}_{\mathrm{x}} \mathrm{MO}_{\mathrm{y}}$ and the milled $\mathrm{LiCoO}$ pellets pressed at $720 \mathrm{MPa}$ at room temperature.

The conduction properties of the prepared amorphous active materials were examined by using AC impedance and DC polarization measurements at the same manner in our previous paper [17]. The calculated electronic and lithium ionic conductivities for the amorphous active materials are summarized in Table 1. All the samples showed the high electronic conductivity of around $10^{-4}-10^{-3} \mathrm{~S} \mathrm{~cm}^{-1}$ at room temperature. In terms of the lithium ionic conductivity, amorphous samples with $\mathrm{Li}_{3} \mathrm{BO}_{3}, \mathrm{Li}_{2} \mathrm{CO}_{3}$ and $\mathrm{LiNO}_{3}$ showed lower conductivity of around $1 \times 10^{-7} \mathrm{~S} \mathrm{~cm}^{-1}$ than that with $\mathrm{Li}_{2} \mathrm{SO}_{4}$ and $\mathrm{Li}_{3} \mathrm{PO}_{4}$ samples. The highest lithium ionic conductivity of $7.8 \times 10^{-7} \mathrm{~S} \mathrm{~cm}^{-1}$ at room temperature was obtained in the $80 \mathrm{LiCoO}_{2} \cdot 20 \mathrm{Li}_{2} \mathrm{SO}_{4}$ sample.

Table 1 Electronic and lithium ionic conductivities of amorphous $80 \mathrm{LiCoO}_{2} \cdot 20 \mathrm{Li}_{x} \mathrm{MO}_{\mathrm{y}}$ active materials

\begin{tabular}{|c|c|c|c|c|c|}
\hline & $\mathrm{Li}_{2} \mathrm{SO}_{4}$ & $\mathrm{Li}_{3} \mathrm{PO}_{4}$ & $\mathbf{L i}_{3} \mathrm{BO}_{3}$ & $\mathbf{L i}_{2} \mathrm{CO}_{3}$ & $\mathbf{L i N O}_{3}$ \\
\hline$\sigma_{\mathrm{e}} / \mathrm{S} \mathrm{cm}^{-1}$ & $1.9 \times 10^{-4}$ & $3.7 \times 10^{-4}$ & $4.6 \times 10^{-4}$ & $2.0 \times 10^{-3}$ & $5.5 \times 10^{-3}$ \\
\hline$\sigma_{\mathrm{Li}+} / \mathrm{S} \mathrm{cm}^{-1}$ & $7.8 \times 10^{-7}$ & $6.4 \times 10^{-7}$ & $1.2 \times 10^{-7}$ & $1.4 \times 10^{-7}$ & $1.0 \times 10^{-7}$ \\
\hline
\end{tabular}

Figure $1 \mathrm{~b}$ shows the cross-sectional SEM images for the pelletized $\mathrm{LiCoO}_{2}$-based amorphous active materials. In the $80 \mathrm{LiCoO}_{2} \cdot 20 \mathrm{Li}_{2} \mathrm{SO}_{4}$, the dense pellet was obtained. The better formability is favorable for achieving high lithium ionic conductivity because of the decrease of grain boundary resistance. However, many voids were observed in the other 
samples. These voids may prevent the lithium ionic conduction, therefore, the lithium ionic conductivity of the amorphous active materials with $\mathrm{Li}_{3} \mathrm{BO}_{3}, \mathrm{Li}_{2} \mathrm{CO}_{3}$ and $\mathrm{LiNO}_{3}$ were lower than that with $\mathrm{Li}_{2} \mathrm{SO}_{4}$. In general, the formability and lithium ionic conductivity of the amorphous samples tend to improve with a decrease in melting point of these crystals as starting materials. The melting points of $\mathrm{Li}_{3} \mathrm{BO}_{3}, \mathrm{Li}_{2} \mathrm{CO}_{3}, \mathrm{LiNO}_{3}, \mathrm{Li}_{2} \mathrm{SO}_{4}$ and $\mathrm{Li}_{3} \mathrm{PO}_{4}$ crystals are, respectively, $820^{\circ} \mathrm{C}, 723^{\circ} \mathrm{C}, 261^{\circ} \mathrm{C}, 859^{\circ} \mathrm{C}$ and $1205^{\circ} \mathrm{C}$. However, the formability and lithium ionic conductivity of the prepared amorphous active materials are not related to the melting point of the starting crystals. The reason why the high lithium ionic conductivity and formability was obtained in the sample with $\mathrm{Li}_{2} \mathrm{SO}_{4}$ has not been clarified yet and further structural analyses are needed to understand those properties.

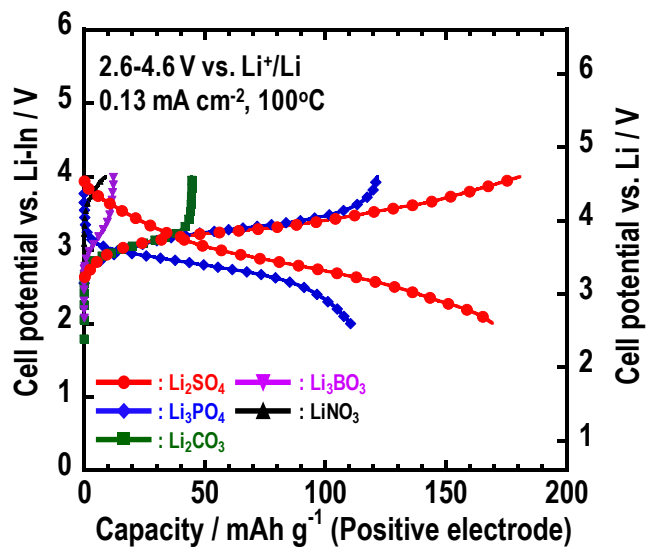

Figure 2 Initial charge-discharge curves of the all-solid-state cells using the amorphous $80 \mathrm{LiCoO}_{2} \cdot 20 \mathrm{Li}_{x} \mathrm{MO}_{y}\left(\mathrm{Li}_{x} \mathrm{MO}_{y}\right.$ : $\mathrm{Li}_{2} \mathrm{SO}_{4}, \mathrm{Li}_{3} \mathrm{PO}_{4}, \mathrm{Li}_{3} \mathrm{BO}_{3}, \mathrm{Li}_{2} \mathrm{CO}_{3}$, and $\mathrm{LiNO}_{3}$ ) positive electrode active materials in the potential region of 2.6-4.6 $\mathrm{V}$ vs. $\mathrm{Li}^{+} / \mathrm{Li}$

All-solid-state cells using the amorphous $\mathrm{LiCoO}_{2}$-based active materials were fabricated to investigate their electrochemical performances. These cells were charged and discharged at the constant current density of $0.13 \mathrm{~mA} \mathrm{~cm}^{-2}$ in the voltage range of 2.6-4.6 $\mathrm{V} \mathrm{vs.} \mathrm{Li}^{+} / \mathrm{Li}$ at $100^{\circ} \mathrm{C}$. The initial charge-discharge curves of the all-solid-state cells using the amorphous active materials are shown in Fig. 2. Only the cells with the $80 \mathrm{LiCoO}_{2} \cdot 20 \mathrm{Li}_{2} \mathrm{SO}_{4}$ and the $80 \mathrm{LiCoO}_{2} \cdot 20 \mathrm{Li}_{3} \mathrm{PO}_{4}$ active materials functioned as secondary batteries. As described above, the electronic conductivity of all the samples is enough high, and thus lithium ionic conductivity limited the capacity of these batteries. The initial charge capacity increased with increasing the lithium ionic conductivity of the amorphous active materials as shown in Table 1. The largest capacity was achieved in the cell with the $80 \mathrm{LiCoO}_{2} \cdot 20 \mathrm{Li}_{2} \mathrm{SO}_{4}$ active material. This result indicates that the larger capacity can be achieved by increasing the ionic conductivity of the active materials. In the glassy electrolytes, conductivity increased by increasing glass-former components, which is so 
called "mixed anion effect" or "mixed former effect" [19,20]. We thus believe that the increase of the component in the amorphous matrix increase the ionic conductivity.
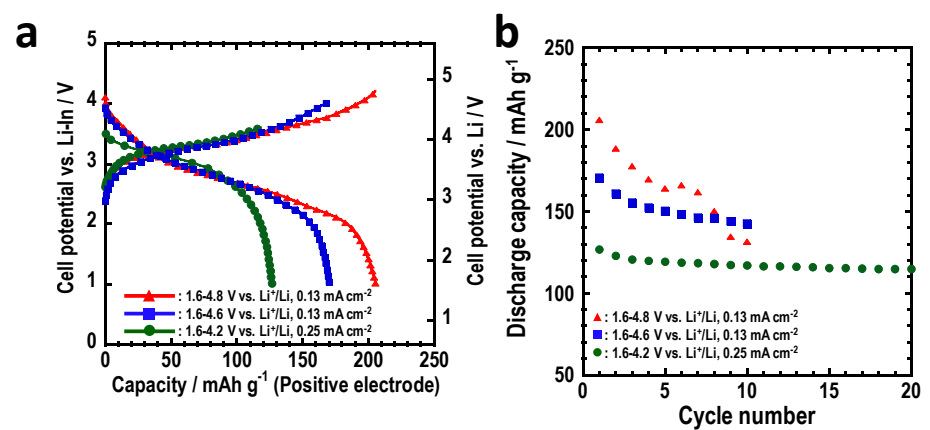

Figure 3 (a) Initial charge-discharge curves of the all-solid-state cells using the amorphous $80 \mathrm{LiCoO}_{2} \cdot 20 \mathrm{Li}_{2} \mathrm{SO}_{4}$ positive electrode active material in the potential region of $1.6-4.8 \mathrm{~V}, 1.6-4.6 \mathrm{~V}$ and $1.6-4.2 \mathrm{~V} \mathrm{vs}$. $\mathrm{Li}^{+} / \mathrm{Li}$. (b) cycle performance of the all-solid-state cells.

The operation conditions for the all-solid-state cells with the amorphous $80 \mathrm{LiCoO}_{2} \cdot 20 \mathrm{Li}_{2} \mathrm{SO}_{4}$ active material were examined. By increasing the charging cut-off voltage, the more lithium ions can be extracted from the active materials. Therefore, the charge cut-off voltage was increased from $4.6 \mathrm{~V}$ to $4.8 \mathrm{~V} \mathrm{vs.} \mathrm{Li}^{+} / \mathrm{Li}$. Figure $3 \mathrm{a}$ shows the initial charge-discharge curves of the all-solid-state cells using the amorphous $80 \mathrm{LiCoO}_{2} \cdot 20 \mathrm{Li}_{2} \mathrm{SO}_{4}$ active material operated in the voltage regions of $1.6-4.8 \mathrm{~V}, 1.6-4.6$ $\mathrm{V}$ and 1.6-4.2 $\mathrm{V}$ vs. $\mathrm{Li}^{+} / \mathrm{Li}$. When the cell was charged to $4.6 \mathrm{~V}$ vs. $\mathrm{Li}^{+} / \mathrm{Li}$, the cell showed the capacity of $168 \mathrm{mAh} \mathrm{g}^{-1}$. When charged to $4.8 \mathrm{~V} \mathrm{vs}$. $\mathrm{Li}^{+} / \mathrm{Li}$, the cell showed the largest

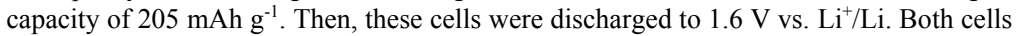
exhibited almost the same voltage profiles. However, the initial discharge capacity was increased from $171 \mathrm{mAh} \mathrm{g}^{-1}$ to $206 \mathrm{mAh} \mathrm{g}^{-1}$ by increasing the charging cut-off voltage from $4.6 \mathrm{~V}$ to $4.8 \mathrm{~V} \mathrm{vs.} \mathrm{Li}^{+} / \mathrm{Li}$. Although the large capacity was achieved by increasing the charging cut-off voltage, rapid capacity fading was observed. This capacity degradation may be caused by the oxygen evolution reaction from the active materials in the high voltage region. Therefore, the charging cut-off voltage was decreased to $4.2 \mathrm{~V} \mathrm{vs.} \mathrm{Li}^{+} / \mathrm{Li}$ to achieve a better cycle performance. The cell operated in the voltage range of $1.6-4.2 \mathrm{~V}$ vs. $\mathrm{Li}^{+} / \mathrm{Li}$ exhibited the initial discharge capacity of $127 \mathrm{mAh} \mathrm{g}^{-1}$ under the constant current density of $0.25 \mathrm{~mA} \mathrm{~cm}^{-2}$. As shown in Fig. 3b, the cell showed better cycle performance with showing the capacity of around $110 \mathrm{mAh} \mathrm{g}^{-1}$ during 20 cycles. 

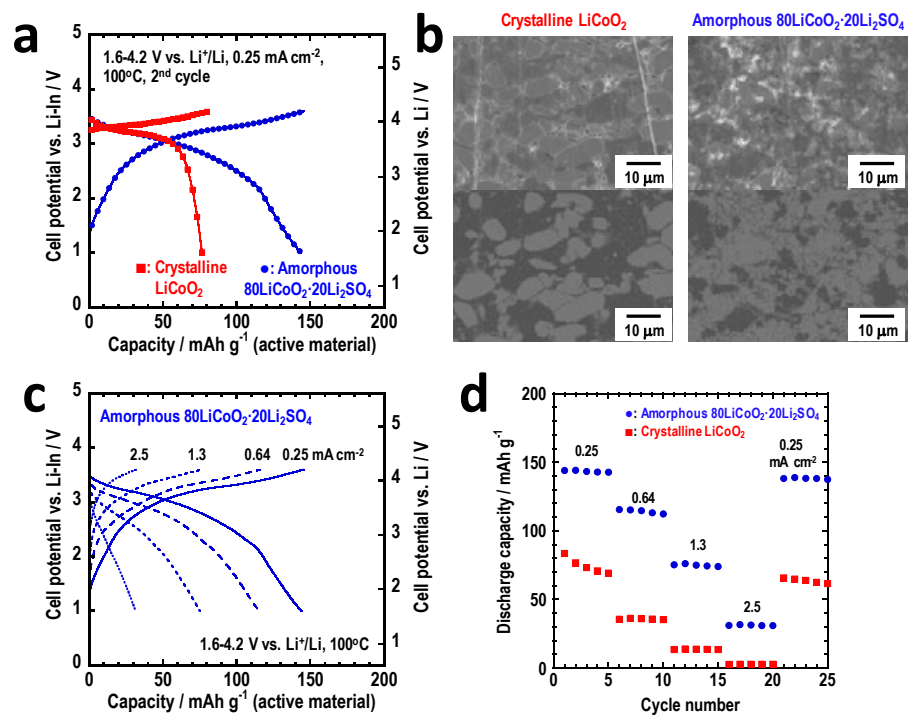

Figure 4 (a) The $2^{\text {nd }}$ charge-discharge curves of the all-solid-state cells using the composite positive electrode composed of the active materials (crystalline $\mathrm{LiCoO}_{2}$ or amorphous $80 \mathrm{LiCoO}_{2} \cdot 20 \mathrm{Li}_{2} \mathrm{SO}_{4}$ ), $\mathrm{Li}_{2.9} \mathrm{~B}_{0.9} \mathrm{~S}_{0.1} \mathrm{O}_{3.1}$ glass-ceramic electrolyte and acetylene black powders. (b) Cross-sectional SEM images (secondary electron (upper) and backscattered electron (lower)) of the composite positive electrode in the all-solid-state cells using the crystalline $\mathrm{LiCoO}_{2}$ or the amorphous $80 \mathrm{LiCoO}_{2} \cdot 20 \mathrm{Li}_{2} \mathrm{SO}_{4}$ active materials. The bright region is corresponding to the active material particle, and the dark one is the $\mathrm{Li}_{2.9} \mathrm{~B}_{0.9} \mathrm{~S}_{0.1} \mathrm{O}_{3.1}$ glass-ceramic electrolyte. (c) The charge-discharge curves of the all-solid-state cells using the amorphous $80 \mathrm{LiCoO}_{2} \cdot 20 \mathrm{Li}_{2} \mathrm{SO}_{4}$ positive electrode active material operated under several current densities at $100^{\circ} \mathrm{C}$. (d) The rate performances of these all-solid-state cells.

Finally, the charge-discharge performance of the amorphous $80 \mathrm{LiCoO}_{2} \cdot 20 \mathrm{Li}_{2} \mathrm{SO}_{4}$ positive electrode active material was compared with that of typical crystalline $\mathrm{LiCoO}_{2}$. Mixtures of the active material $(67.3 \mathrm{wt} \%)$ and the $\mathrm{Li}_{2.9} \mathrm{~B}_{0.9} \mathrm{~S}_{0.1} \mathrm{O}_{3.1}$ glass-ceramic electrolyte $(28.8 \mathrm{wt} \%)$ and acetylene black (3.8 wt\%) powders were used as the composite positive electrode. Charge-discharge curves of the all-solid-state cells (Li$\mathrm{In} / \mathrm{Li}_{2.9} \mathrm{~B}_{0.9} \mathrm{~S}_{0.1} \mathrm{O}_{3.1}$ glass-ceramic/composite electrodes) are shown in Fig. 4a. Although the crystalline $\mathrm{LiCoO}_{2}$ exhibited the capacity of about $80 \mathrm{mAh} \mathrm{g}^{-1}$, and the capacity gradually decreased during cycling. This capacity deterioration was caused by inhomogeneous lithium extraction/insertion reaction in the composite positive electrode layer [21]. On the other hand, the amorphous $80 \mathrm{LiCoO}_{2} \cdot 20 \mathrm{Li}_{2} \mathrm{SO}_{4}$ showed a larger capacity of about 150 $\mathrm{mAh} \mathrm{g}^{-1}$. Figure $4 \mathrm{~b}$ shows the cross-sectional SEM images for the composite positive electrodes using the crystalline $\mathrm{LiCoO}_{2}$ or the amorphous $80 \mathrm{LiCoO}_{2} \cdot 20 \mathrm{Li}_{2} \mathrm{SO}_{4}$ active materials after charge-discharge cycling. Although, many small voids were observed, a denser electrode layer was achieved with the amorphous $80 \mathrm{LiCoO}_{2} \cdot 20 \mathrm{Li}_{2} \mathrm{SO}_{4}$ active material. The utilization of the active material increased because better lithium ion 
conduction pathway was formed by means of better formability of the amorphous $80 \mathrm{LiCoO}_{2} \cdot 20 \mathrm{Li}_{2} \mathrm{SO}_{4}$ active material. Rate performances of the cells using these positive electrode active materials are shown in Figs. $4 \mathrm{c}$ and $4 \mathrm{~d}$. The all-solid-state cell with amorphous $80 \mathrm{LiCoO}_{2} \cdot 20 \mathrm{Li}_{2} \mathrm{SO}_{4}$ operated as a secondary battery even under the high current density of $2.5 \mathrm{~mA} \mathrm{~cm}^{-2}\left(0.4 \mathrm{C}\right.$ rate; $\left.1 \mathrm{C}=342 \mathrm{~mA} \mathrm{~g}^{-1}\right)$ at $100^{\circ} \mathrm{C}$. The better rate performance was successfully achieved because the lithium ion conductivity of the active material increased. These results clearly indicated that the electrochemical properties of $\mathrm{LiCoO}_{2}$ active material were improved by the amorphization with $\mathrm{Li}_{2} \mathrm{SO}_{4}$.

\section{Conclusions}

Amorphous positive electrode materials composed of $\mathrm{LiCoO}_{2}$ and one of $\mathrm{Li}_{2} \mathrm{SO}_{4}$, $\mathrm{Li}_{3} \mathrm{PO}_{4}, \mathrm{Li}_{3} \mathrm{BO}_{3}, \mathrm{Li}_{2} \mathrm{CO}_{3}$ and $\mathrm{LiNO}_{3}$ were synthesized by a mechanical milling technique. XRD patterns showed that amorphous samples were mainly obtained and the peaks attributable to cubic $\mathrm{LiCoO}_{2}$ was partially observed. The similar structures were obtained at the all compositions as the amorphous $\mathrm{LiCoO}_{2}-\mathrm{Li}_{2} \mathrm{SO}_{4}$ active materials, in which nanosized crystalline cubic $\mathrm{LiCoO}_{2}$ was dispersed in the amorphous $\mathrm{LiCoO}_{2}-\mathrm{Li}_{2} \mathrm{SO}_{4}$ matrix. All the amorphous active materials were mixed conductors with electron and lithium ion conductivities. These amorphous active materials showed high electronic conductivity of around $10^{-4}-10^{-3} \mathrm{~S} \mathrm{~cm}^{-1}$ at room temperature. The highest ionic conductivity of $7.8 \times 10^{-7}$ $\mathrm{S} \mathrm{cm}^{-1}$ at room temperature was obtained at the $80 \mathrm{LiCoO}_{2} \cdot 20 \mathrm{Li}_{2} \mathrm{SO}_{4}(\mathrm{~mol} \%)$ composition. All-solid-state cells using these amorphous positive electrode active materials were fabricated and their electrochemical performances were examined at $100^{\circ} \mathrm{C}$. The capacity increased with increasing the lithium ionic conductivity of the active materials, and the largest capacity was achieved at $80 \mathrm{LiCoO}_{2} \cdot 20 \mathrm{Li}_{2} \mathrm{SO}_{4}$. These results indicate that the utilization of the amorphous active materials can be increased by increasing the lithium ionic conductivity of the active materials.

The all-solid-state cells with the $80 \mathrm{LiCoO}_{2} \cdot 20 \mathrm{Li}_{2} \mathrm{SO}_{4}$ active material showed the large initial capacity of more than $200 \mathrm{mAh} \mathrm{g}^{-1}$ in the potential region of $1.6-4.8 \mathrm{~V} \mathrm{vs.} \mathrm{Li}^{+} / \mathrm{Li}$. Unfortunately, the capacity gradually decreased during cycles. This degradation would be caused by the instability of the electrode active material in the high potential region. On the other hand, the cell showed better cycle performance in 1.6-4.2 $\mathrm{V} \mathrm{vs.} \mathrm{Li}^{+} / \mathrm{Li}$. This amorphous active material showed better rate and cycle performances than the crystalline $\mathrm{LiCoO}_{2}$ positive electrode active material in the all-oxide solid-state cells. We believe that the amorphous materials synthesized from the combination of lithium transition metal oxides and lithium oxyacids are promising active materials for all-solid-state batteries with high energy density.

\section{References:}

[1] K. Takada, Acta Mater., 64, 759 (2013).

[2] F. Mizuno, A. Hayashi, K. Tadanaga, M. Tatsumisago, Adv. Mater., 17, 918 (2005).

[3] Y. Seino, T. Ota, K. Takada, A. Hayashi, M. Tatsumisago, Energy Environ. Sci., 7, 627 (2014).

[4] A. Hayashi, D. Furusawa, Y. Takahashi, K. Minami, M. Tatsumisago, Phys. Chem. Glasses: Eur. J. Glass Sci. Technol. B, 54, 109 (2013).

[5] M. Tatsumisago, H. Narita, T. Minami, M. Tanaka, J. Am. Ceram. Soc., 66, C210 (1983).

[6] M. Tatsumisago, R. Takano, K. Tadanaga, A. Hayashi, J. Power Sources, 270, 603 (2014).

[7] K. Nagao, A. Hayashi, M. Tatsumisago, J. Ceram. Soc. Japan, 124, 915 (2016).

[8] M. Tatsumisago, R. Takano, M. Nose, K. Nagao, A. Kato, A. Sakuda, K. Tadanaga, A. Hayashi, J. Ceram. Soc. Japan, 125, 433 (2017). 
[9] K. Nagao, M. Nose, A. Kato, A. Sakuda, A. Hayashi, M. Tatsumisago, Solid State Ionics, 308, 68 (2017).

[10] K. Mizushima, P. C. Jones, P. J. Wiseman, J. B. Goodenough, Mat. Res. Bull. 15, 783 (1980).

[11] T. Ohzuku, Y. Makimura, Chem. Lett., 7, 642 (2001).

[12] N. Yabuuchi, T. Ohzuku, J. Power Sources, 119-121, 171 (2003).

[13] N. Machida, R. Fuchida, T. Minami, J. Electrochem. Soc., 136, 2133 (1989).

[14] A. Hayashi, T. Matsuyama, A. Sakuda, M. Tatsumisago, Chem. Lett., 41, 886 (2012).

[15] T. Matsuyama, A. Hayashi, T. Ozaki, S. Mori, M. Tatsumisago, J. Mater. Chem. A, 3, 14142 (2015).

[16] Y. Sabi, S. Sato, S. Hayashi, T. Furuya, S. Kusanagi, J. Power Sources, 258, 54 (2014).

[17] K. Nagao, A. Hayashi, M. Deguchi, H. Tsukasaki, S. Mori, M. Tatsumisago, J. Power Sources, 348, 1 (2017).

[18] M. N. Obrovac, O. Mao, J. R. Dahn, Solid State Ionics, 112, 9 (1998).

[19] M. Tatsumisago, N. Machida, T. Minami, J. Ceram. Soc. Japan, 95, 197 (1987).

[20] Y. Deng, C. Eames, B. Fleutot, R. David, J.-N. Chotard, E. Suard, C. Masquelier, M. S. Islam, ASC Appl. Mater. Interfaces, 9, 7050 (2017).

[21] M. Otoyama, Y. Ito, A. Hayashi, M. Tatsumisago, J. Power Sources, 302, 419 (2016). 